\title{
Phosphodiesterase III Inhibitor Cilostazol Protects Amyloid $\beta$-Induced Neuronal Cell Injury via Peroxisome Proliferator-Activated Receptor $-\gamma$ Activation
}

\author{
Sun Haeng Park', Ji Hyun Kim', Sun Sik Bae ${ }^{2}$, Ki Whan Hong ${ }^{2}$, Byung Tae Choi ${ }^{1}$ and Hwa Kyoung \\ Shin $^{1}$ *
}

\author{
${ }^{1}$ Division of Meridian and Structural Medicine, School of Korean Medicine, Pusan National University, Yangsan 626-870, Korea \\ ${ }^{2}$ Department of Pharmacology, School of Medicine, Pusan National University, Yangsan 626-870, Korea
}

Received February 21, 2011 /Accepted March 9, 2011

\begin{abstract}
The neurotoxicity of aggregated amyloid $\beta(\mathrm{A} \beta)$ has been implicated as a critical cause in the pathogenesis of Alzheimer's disease (AD). It can cause neurotoxicity in AD by evoking a cascade of apoptosis to neuron. Here, we investigated the neuroprotective effects of cilostazol, which acts as a phosphodiesterase III inhibitor, on $A \beta_{25-35}$-induced cytotoxicity in mouse neuronal cells and cognitive decline in the C57BL/6J AD mouse model via peroxisome proliferator-activated receptor (PPAR)- $\gamma$ activation. $\mathrm{A} \beta_{25-35}$ significantly reduced cell viability and increased the number of apoptotic-like cells. Cilostazol treatment recovered cells from $A \beta$-induced cell death as well as rosiglitazone, a PPAR- $\gamma$ activator. These effects were suppressed by GW9662, an antagonist of PPAR- $\gamma$ activity, indicative of a PPAR- $\gamma$ -mediated signaling. In addition, cilostazol and rosiglitazone also restored PPAR- $\gamma$ activity levels that had been altered as a result of $A \beta_{25-35}$ treatment, which were antagonized by GW9662. Furthermore, cilostazol also markedly decreased the number of apoptotic-like cells and decreased the Bax/Bcl-2 ratio. Intracerebroventricular injection of $A \beta_{25-35}$ in $\mathrm{C} 57 \mathrm{BL} / 6 \mathrm{~J}$ mice resulted in impaired cognitive function. Oral administration of cilostazol $(20 \mathrm{mg} / \mathrm{kg})$ for 2 weeks before $A \beta_{25-35}$ injection and once a day for 4 weeks post-surgery almost completely prevented the $A \beta_{25-35}$-induced cognitive deficits, as did rosiglitazone. Taken together, our findings suggest that cilostazol could attenuate $A \beta_{25-35}$-induced neuronal cell injury and apoptosis as well as promote the survival of neuronal cells, subsequently improving cognitive decline in AD, partly because of PPAR- $\gamma$ activation. The phosphodiesterase III inhibitor cilostazol may be the basis of a novel strategy for the therapy of AD.
\end{abstract}

Key words : Alzheimer's disease, amyloid $\beta$, apoptosis, cell injury

\section{Introduction}

Alzheimer's disease (AD) is neuropathological characterized by deposition of amyloid $\beta(A \beta)$-containing plaques and intracellular neurofibrillary tangles and loss of neurons in the brain, along with progressive cognitive impairment [7,8]. Excessive accumulation of $A \beta$ in the brain is a possible cause of neurodegeneration [6,28], although the precise mechanism by which $A \beta$ induces neuronal death remains unknown $[11,31]$. Therefore, therapeutic intervention with attenuating $\mathrm{A} \beta$-mediated neurotoxicity may help in preventing neurodegeneration and clinical decline in $\mathrm{AD}$ patients.

Cilostazol [OPC-13013, 6-[4-(1-cyclohexyl-1 H-tetrazol-5-yl) butoxy]-3,4-dihydro-2-(1H)-quinolinone] increases intracellular cyclic AMP (cAMP) levels by inhibiting type III phosphodiesterase. Previous studies have shown that cil-

\footnotetext{
*Corresponding author

Tel : +82-51-510-8476, Fax : +82-51-510-8437

E-mail : julie@pusan.ac.kr
}

ostazol possesses many pharmacological activities, including anti-inflammatory, anti-oxidative, and anti-apoptotic effects in the brain [12]. Cilostazol was shown to prevent cerebral hypoperfusion-induced cognitive impairment and white matter damage in a rat model in which the occlusion of the common carotid artery via bilateral ligation [18]. A more recent preliminary study conducted in human patients with moderate $\mathrm{AD}$ reported that a combination therapy of donepezil and cilostazol maintained improvement or preserved the current status until the end of the follow-up period [2]. Therefore, cilostazol may prevent the neuronal death and cognitive impairment caused by $\mathrm{AD}$.

Peroxisome proliferator-activated receptor (PPAR)- $\gamma$ is a nuclear transcription factor belonging to the PPAR family. Although considerable research has shown a role for PPAR$\gamma$ in adipose differentiation [27] and in the regulation of inflammation [15], little is known about its possible functions in neurons. Recently, PPAR- $\gamma$ agonists have raised the hope that PPAR- $\gamma$ could become a drug target for the treat- 
ment of neurological disease such as AD. This beneficial effect of PPAR- $\gamma$ agonists in AD was mediated by controlling neuroinflammation and reducing neuronal death $[19,34]$. We recently reported that cilostazol significantly elevated endogenous PPAR- $\gamma$ transcriptional activity in COS-7 cells and human umbilical vein endothelial cells [22] and suppressed proinflammatory markers via activation of PPAR- $\gamma$ transcription in $\mathrm{db} / \mathrm{db}$ mice [23]. Therefore, cilostazol could decrease neuronal death and improve cognitive deficit via PPAR- $\gamma$ activation in AD. However, there is no direct evidence to support the neuroprotective properties of cilostazol in case of $A \beta$ insult. The aim of this study was to examine whether cilostazol has neuroprotective effects against $A B$ -induced cell death and cognitive deficits.

We hypothesized that the phosphodiesterase III inhibitor cilostazol decreased neuronal cell death via PPAR- $\gamma$ activation, subsequently improving the cognitive decline in AD. To test this hypothesis, we investigated the neuroprotective effects of the cilostazol on $A \beta$-induced cell death and $A B$ -induced expression of apoptotic proteins in mouse neuronal cells and on spatial learning and memory in $A \beta_{25-35}$-injected mice compared with rosiglitazone, a PPAR- $\gamma$ activator.

\section{Materials and Methods}

\section{Neuronal primary cell culture}

Primary neural cell cultures from E14 ICR mouse brains were prepared as described previously [29]. Briefly, the brain tissues were dissected and were incubated in HBSS (Sigma-Aldrich, St. Louis, MO) containing 0.5\% trypsin at $37^{\circ} \mathrm{C}$ for $30 \mathrm{~min}$. Dissociated cells were plated on poly - D lysine - coated dishes. After 1 day, the plates were washed extensively with HBSS to remove residual non-adherent cells. Adherent cells were harvested and cultured in Dulbecco's modified Eagle's medium (DMEM, Gibco, Carlsbad, CA) with $10 \%$ fetal bovine serum, $100 \mathrm{U} / \mathrm{ml}$ penicillin, $100 \mu \mathrm{g} / \mathrm{ml}$ streptomycin (Hyclone, Logan, UT), 10 $\mathrm{ng} / \mathrm{ml}$ basic fibroblast growth factor (bFGF), and $10 \mathrm{ng} / \mathrm{ml}$ epidermal growth factor (EGF) in a humidified atmosphere containing $5 \% \mathrm{CO}_{2}$ in air at $37^{\circ} \mathrm{C}$. To induce cell injury, cells were incubated with $30 \mu \mathrm{M} \mathrm{A} \beta_{25-35}$ for $24 \mathrm{hr}$.

\section{MTT assay}

The MTT assay was a standard method used to assess cell viability. Neuronal cells $\left(1 \times 10^{5}\right.$ cells/well) were seeded in 96-well microtiter plates. The cells were treated with 30 $\mu \mathrm{M} \mathrm{A} \beta_{25-35}$ and various concentration cilostazol $(1,3,10$ or $30 \mu \mathrm{M})$ for $24 \mathrm{hr}$. Subsequently, $20 \mu \mathrm{l}$ MTT solution $(5 \mathrm{mg} / \mathrm{ml}$ in PBS) was added to each well, and the plates were incubated at $37^{\circ} \mathrm{C}$ for $4 \mathrm{hr}$, and $150 \mu \mathrm{l}$ dimethyl sulfoxide (DMSO) was added to dissolve the formazan crystals. The absorbance was measured at $540 \mathrm{~nm}$ using a spectrophotometer (Molecular devices, Sunnyvale, CA). Cilostazol was donated by Otsuka Pharmaceutical (Tokushima, Japan).

\section{Promotor assay}

The PPAR $\gamma$ (Peroxisome proliferator-activated receptor) activity was measured by luciferase reporter assays. Neuronal cells in 12-well plates were co-transfected with a firefly luciferase gene tagged with pGL3-PPRE and renilla luciferase using Lipofectamine 2000 (Invitrogen, Carlsbad, CA). Medium was replaced with fresh medium after $6 \mathrm{hr}$. Twenty-four hours post-transfection, cells were stimulated with $30 \mu \mathrm{M} \mathrm{A} \beta_{25-35}$ and various concentration cilostazol (1, 3, 10 or $30 \mu \mathrm{M}$ ). Luciferase activity was assayed $24 \mathrm{hr}$ later using a dual-luciferase reporter assay system (Promega, Madison, WI).

\section{Hoechst 33258 staining}

The characteristic features of apoptotic nuclei were assessed by Hoechst 33258 fluorescent dye. Neuronal cells were fixed with $4 \%$ paraformaldehyde and then stained with $10 \mu \mathrm{g} / \mathrm{ml}$ of Hoechst 33258 (Sigma-Aldrich) for $10 \mathrm{~min}$. Nuclear morphology was visualized using Fluorescence microscope (Axio Imager, Carl Zeiss, Jena, Germany). The number of cells with apoptotic morphology appearing condensed or fragmented nuclei was counted.

\section{Western blotting}

Proteins from mouse neuronal cells were isolated according to standard techniques, separated by $10 \%$ sodium dodecyl sulfate-polyacrylamide gel electrophoresis (SDSPAGE), and transferred onto a nitrocellulose membrane (Amersham Biosciences, Piscataway, NJ). Blots were probed for Bcl-2 (Calbiochem, Gibbstown, NJ) and Bax (Santa Cruz Biotechnology, Santa Cruz, CA) followed by incubation with secondary antibody conjugated with horseradish peroxidase. The intensity of chemiluminescence was measured by an ImageQuant LAS 4000 apparatus (GE Healthcare Life Sciences, Buckinghamshire, UK). The membrane was reprobed with an anti- $\beta$-actin antibody (Sigma-Aldrich) as an internal control. 


\section{$A \beta_{25-35}$ injection model}

To evaluate the effects of cilostazol on A $\beta$-induced cognitive impairment, a mouse model produced with modification of previously reported methods [21,30] was used. Male C57BL/6J mice (20-25 g) were housed under diurnal lighting conditions and allowed food and tap water ad libitum All animal procedures were in accordance with Pusan National University guidelines for animal research, and were approved by the university's Animal Care and Use Committee (PNU-2009-0043). Mice were anesthetized with chloral hydrate (45 mg/kg, intraperitoneally) and were allowed spontaneous respiration throughout the surgical procedures. The depth of anesthesia was checked by the absence of cardiovascular changes in response to tail pinch. Rectal temperature was kept at $36.5-37.5^{\circ} \mathrm{C}$ using a thermostatically controlled heating mat (Panlab, Harvard Apparatus, Holliston, MA). A $\beta_{25-35}$ (Sigma-Aldrich; $10 \mathrm{nmol}$ in $5 \mu \mathrm{l}$ of saline) was injected intracerebroventricularly (icv) into the mice, aimed at $1 \mathrm{~mm}$ lateral to the midline, $0.5 \mathrm{~mm}$ posterior to the bregma and $3 \mathrm{~mm}$ deep using a $25 \mu \mathrm{l}$ Hamilton syringe with a 26 gauge needle (Hamilton, Reno, $\mathrm{NV}$ ) at a rate of $0.5 \mu \mathrm{l} / \mathrm{min}$ using a stereotaxic injector (KD Scientific, Holliston, MA). The sham group of mice received icv injections of an equal volume of saline. Either cilostazol $(20 \mathrm{mg} / \mathrm{kg})$, rosiglitazone $(10 \mathrm{mg} / \mathrm{kg}$ ) or an equal volume of DMSO (the vehicle) was given orally 2 weeks before $A \beta$ 25-35 injection and daily for 4 weeks post-surgery.

\section{Morris water maze task}

Spatial learning and memory deficits were assessed using the Morris water maze task as described previously [3,30] with minor modification. The experiment was performed on mice after 4 weeks $A \beta_{25-35}$ injection period. The maze consisted of a $1.15 \mathrm{~m}$-diameter pool which was painted flat white. A $10 \mathrm{~cm}$-diameter platform was placed halfway between the center of the pool and the edge, and was positioned $1 \mathrm{~cm}$ below the surface of the water. The water in the pool was made opaque by the addition of powdered milk. The water temperature was $19-21^{\circ} \mathrm{C}$. The water tank was located in a test room, in which there were many cues external to the maze. The position of the cues remained unchanged throughout the water-maze task. Each mouse was subjected to a series of five trials per day. For each trial, mice were randomized to one of four directional starting locations (north, south, east and west) and were placed in the pool facing the wall. During the four subsequent training days, the mice were given three or five trial sessions per day with the platform in place before an $A \beta_{25-35}$ injection. When a mouse located the platform, it was permitted to remain on it for $10 \mathrm{sec}$. If the mouse did not locate the platform within $180 \mathrm{sec}$, it was placed on the platform for $10 \mathrm{sec}$. Mice were given a maximum of $180 \mathrm{sec}$ to find the submerged platform. Swimming was video tracked, and latency time from the platform was analyzed by Smart software (Panlab, Barcelona, Spain).

\section{Data analysis}

The data were expressed as mean \pm SEM. Statistical comparisons were performed using paired or unpaired Student's $t$ test and one-way analysis of variance (ANOVA) or two-way ANOVA for repeated measures followed by Fisher's protected least significant difference test. $p<0.05$ was considered statistically significant.

\section{Results}

Cilostazol protected neuronal cells against $A \beta$
25-35-induced cytotoxicity

MTT assay was used to test the effect of cilostazol on the toxicity of $A \beta_{25-35}$. At concentrations between 1 and $30 \mu \mathrm{M}$, cilostazol alone did not cause any apparent cytotoxicity (data not shown). $30 \mu \mathrm{M} \mathrm{A} \beta_{25-35}$ significantly decreased the cell viability $(60.09 \pm 3.52 \%, p<0.01$ vs. control group), which were significantly attenuated by $30 \mu \mathrm{M}$ cilostazol to $89.25 \pm 0.62 \%$ ( $p<0.01$ vs. $A \beta_{25-35}$-treated alone group) and $10 \mu \mathrm{M}$ rosiglitazone, a PPAR- $\gamma$ agonist to $91.44 \pm 4.25 \%$ ( $p<0.01$ vs. A $\beta$ 25-35-treated alone group) (Fig. 1). Co-treatment with $5 \mu \mathrm{M}$ GW9662, a PPAR- $\gamma$ antagonist significantly reversed the increased cell viability induced by cilostazol $(71.59 \pm 2.50 \%$, $p<0.01$ vs. cilostazol-treated group) and rosiglitazone (57.49 $\pm 3.48 \%, p<0.01$ vs. rosiglitazone-treated group). Thus, the results of the MTT assay showed that cilostazol could block cytotoxic effects of $A \beta_{25-35}$ via PPAR- $\gamma$ activation in mouse neuronal cells.

\section{Cilostazol restored PPAR-y activation in neuronal} cells

$\mathrm{A} \beta_{25-35}$ significantly decreased PPAR $\gamma$ transcription activity $(0.57 \pm 0.02$ fold of the control, $p<0.01$ vs. control group), which was markedly reversed by cilostazol in dose-depend- 

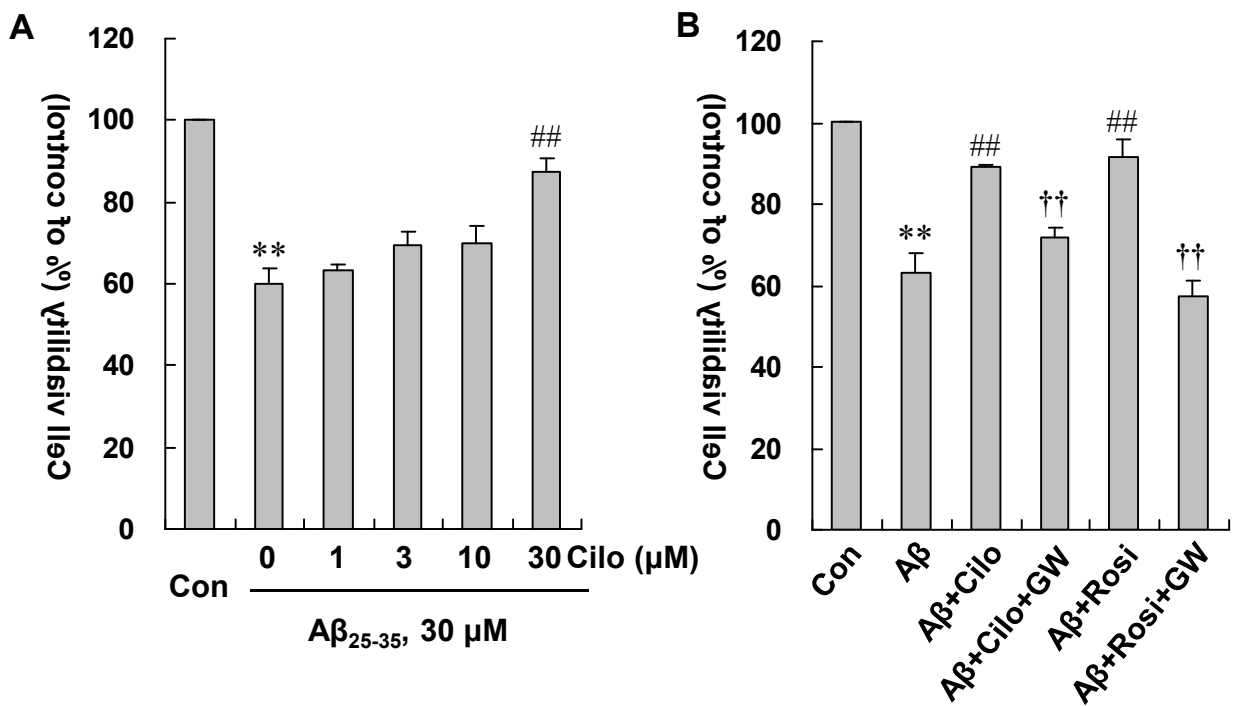

Fig. 1. Cilostazol protects $A \beta_{25-35}$-induced neurotoxicity. (A) Mouse neuronal cells treated with or without cilostazol (Cilo; 1 - 30 $\mu \mathrm{M})$, followed by incubation with $30 \mu \mathrm{M} \mathrm{A} \beta_{25-35}$ for $24 \mathrm{hr}$. After this incubation, cell viability was determined using the MTT assay. (B) The effect of $30 \mu \mathrm{M}$ cilostazol against A $\beta$-induced neurotoxicity was assessed in the absence and presence of $5 \mu \mathrm{M}$ GW9662 (GW) compared with $10 \mu \mathrm{M}$ rosiglitazone (Rosi). Results are shown as the mean \pm SEM and represent four independent experiments. ${ }^{* *}, p<0.01$ vs. control group (Con); \#\#, $p<0.01$ vs. A $\beta_{25-35}$-treated alone group; ${ }^{\dagger \dagger}, p<0.01$ vs. $A \beta+$ cilostazol group or $A \beta+$ rosiglitazone group.

ent manners (Fig. 2A). The activity induced by $30 \mu \mathrm{M}$ cilostazol and $10 \mu \mathrm{M}$ rosiglitazone increased to $2.42 \pm 0.16$ fold and $1.35 \pm 0.107$ fold ( $p<0.01$ vs. $A \beta_{25-35}$-treated alone group). Increased PPAR- $\gamma$ activities stimulated by cilostazol and rosiglitazone were significantly antagonized by GW9662 (5 $\mu \mathrm{M})$ (Fig. 2B). Cilostazol alone $(30 \mu \mathrm{M})$ or rosiglitazone alone $(10$ $\mu \mathrm{M})$ without treatment of $\mathrm{A} \beta_{25-35}$ also significantly elevated PPAR $\gamma$ transcription activity to $2.28 \pm 0.28$ fold and $1.60 \pm 0.08$ fold ( $p<0.01$ vs. control group).

\section{Cilostazol suppressed $\quad A \beta_{25-35}$-induced apoptosis in neuronal cells}

Antiapoptotic properties of cilostazol were verified by quantitation of Hoechst 33258 stained apoptotic nuclei. In the control group, the nuclei of neuronal cells were round and homogeneously stained. After $24 \mathrm{hr}$ exposure of $30 \mu \mathrm{M}$ $A \beta_{25-35}$, the cells exhibited highly condensed and fragmented nuclei morphology, which are the typical characteristics of apoptosis $(7.50 \pm 0.79 \%$ and $44.67 \pm 1.46 \%$ in the control group and $\mathrm{A} \beta_{25-35}$-treated alone group, respectively, $p<0.01$, Fig. 3). Treatment with $30 \mu \mathrm{M}$ cilostazol decreased the number of apoptotic cells compared to the cells treated with $A \beta_{25-35}$ alone $(7.00 \pm 1.30 \%, p<0.01$, Fig. 3). Thus, the results showed that cilostazol suppressed $A \beta_{25-35}$-induced DNA damage in neuronal cells.
Effect of cilostazol on the expression of proapoptotic proteins in $A \beta_{25-35}$-induced neuronal cells

To explore the molecular mechanisms underlying $A \beta$ 25-35-induced cell apoptosis, we examined the expression of $\mathrm{Bcl}-2$ and Bax to determine whether the regulation of these cell death-associated proteins might be responsible for the protective effect of cilostazol. Exposure cells to $A \beta_{25-35}$ induced a robust increase in the protein level of Bax, and a strong change in the protein level of $\mathrm{Bcl}-2$, and the ratio of $\mathrm{Bax} / \mathrm{Bcl}-2$ expression increased approximate 3-fold in $\mathrm{A} \beta_{25-35}$ treatment alone compared with the control using western blot analysis (Fig. 4). While, cilostazol $(30 \mu \mathrm{M})$ significantly reduced the $A \beta_{25-35}$-induced increase of the $\mathrm{Bax} / \mathrm{Bcl}-2$ ratio to $129.21 \pm 16.01 \%$ ( $p<0.01$ vs. control) in a similar degree as did rosiglitazone $(10 \mu \mathrm{M})$, both of which were significantly antagonized by GW9662 $(5 \mu \mathrm{M})$. The results suggested that cilostazol could prevent $A \beta_{25-35}$-induced apoptosis, at least in part, via PPAR- $\gamma$-mediated regulation of Bcl-2 and Bax expression.

Cilostazol improved cognitive impairment in $A \beta_{25-35}$ -injected mice

Learning and memory deficits are the early and critical symptoms of $\mathrm{AD}$ [16]. We investigated the preventive effect of cilostazol, by administering cilostazol beginning 2 weeks 
A

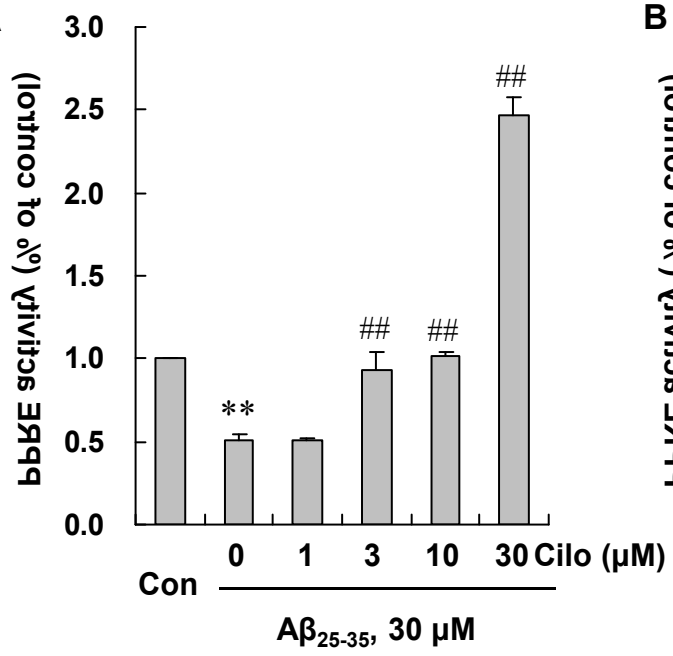

B $3.0[\quad$ \#\#

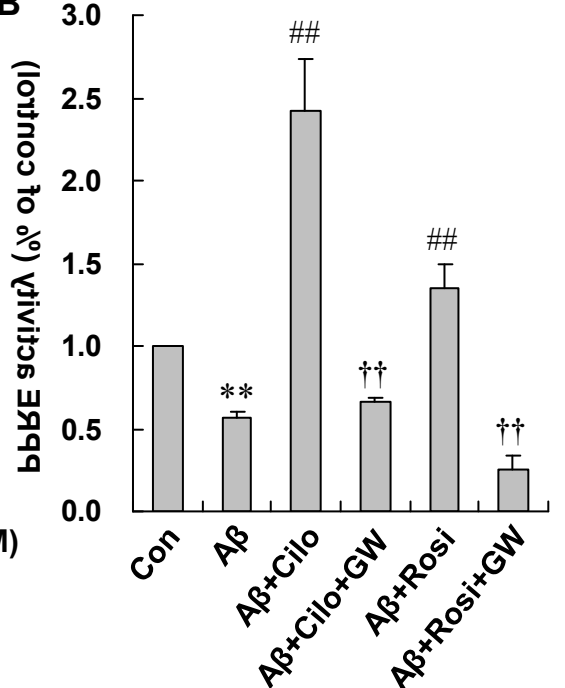

Fig. 2. Cilostazol restores PPAR $\gamma$ activation. (A) Mouse neuronal cells were transiently transfected with PPRE-pGL3, a renilla luciferase control reporter vector, and then treated with or without cilostazol (Cilo; $1-30 \mu \mathrm{M}$ ), followed by incubation with 30 $\mu \mathrm{M} \mathrm{A} \beta_{25-35}$ for $24 \mathrm{hr}$. After this incubation, PPAR $\gamma$ transcription activity was determined using Luciferase reporter assay. (B) The effect of $30 \mu \mathrm{M}$ cilostazol against A $\beta$-induced decrease of PPAR $\gamma$ transcription activity was assessed in the absence and presence of $5 \mu \mathrm{M}$ GW9662 (GW) compared with $10 \mu \mathrm{M}$ rosiglitazone (Rosi). Results are shown as the mean \pm SEM and represent five independent experiments. ${ }^{* *}, p<0.01$ vs. control group (Con); \#\#, $p<0.01$ vs. $\mathrm{A} \beta_{25-35}$-treated alone group; ${ }^{\dagger \dagger}$, $p<0.01$ vs. $\mathrm{A} \beta+$ cilostazol group or $\mathrm{A} \beta+$ rosiglitazone group.

A

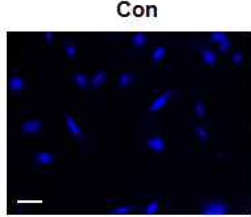

$A \beta_{25-35}$

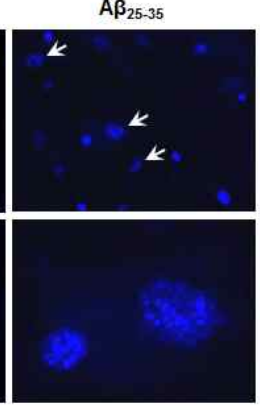

$\mathbf{B}$
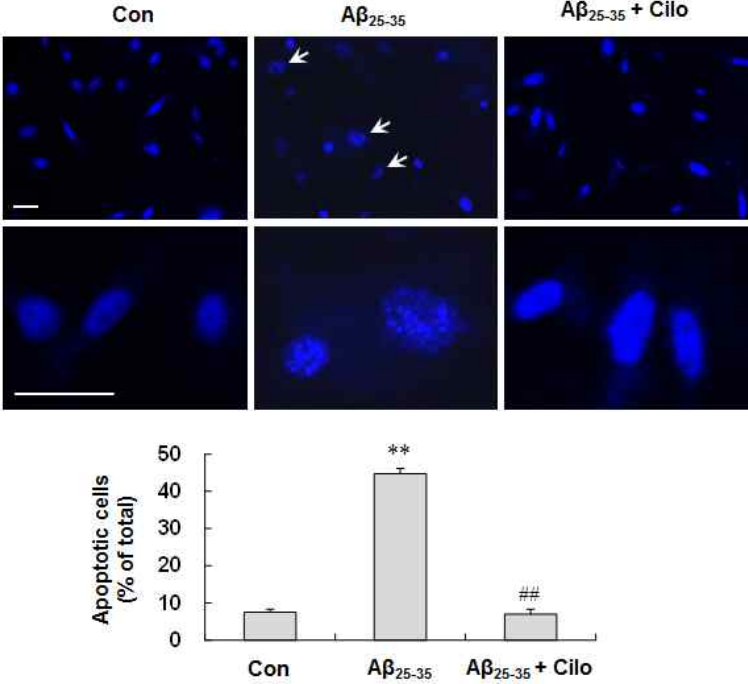

Fig. 3. Cilostazol prevents $A \beta_{25-35}$-induced apoptosis. (A) Mouse neuronal cells, with or without treated $30 \mu \mathrm{M}$ cilostazol (Cilo) which were exposed to $A \beta_{25-35}$ for $24 \mathrm{hr}$, and then were subjected to Hoechst 33258 staining and viewed under a fluorescence microscope. Apoptotic cells were identified by morphological changes, such as nuclei condensation and fragmentation (arrows). (B) Quantification of abnormal nuclei after exposure of $A \beta_{25-35}$ in the presence or absence of $30 \mu \mathrm{M}$ cilostazol. Results are shown as the mean $\pm \mathrm{SEM}$ and represent six independent experiments. ${ }^{* *}, p<0.01$ vs. control group (Con); \#\#, $p<0.01$ vs. $\mathrm{A} \beta_{25-35}$-treated alone group. Scale bar is $10 \mu \mathrm{m}$.
A

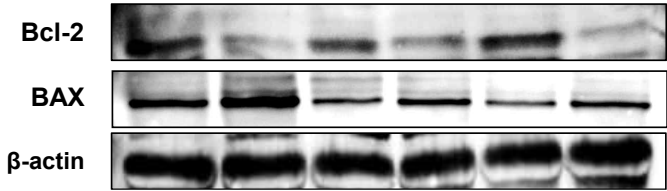

B

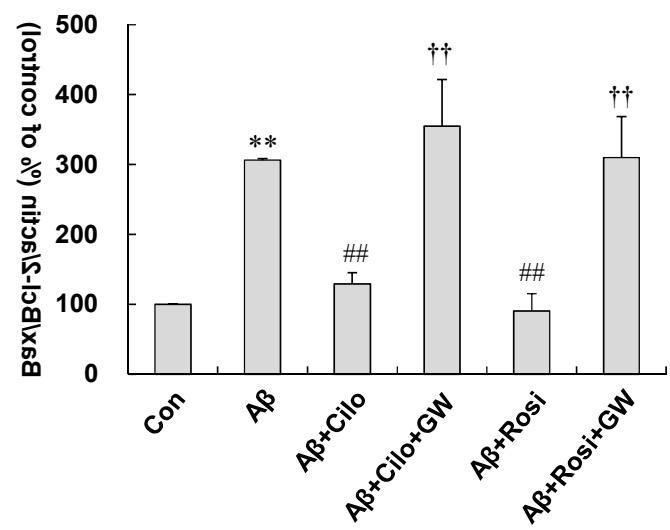

Fig. 4. Effect of cilostazol on the expression of Bcl-2 family proteins in $A \beta_{25-35}$-induced neuronal cells. (A) Effect of 30 $\mu \mathrm{M}$ cilostazol (Cilo) in comparison with $10 \mu \mathrm{M}$ rosiglitazone (Rosi) on $A \beta_{25-35}$-induced Bcl-2 and Bax protein expressions in mouse neuronal cells by western blotting. (B) Effect of cilostazol on the ratio of values of $\mathrm{Bax} / \mathrm{BCl}-2 /$ actin. Densitometric analysis is mean $\pm \mathrm{SEM}$ of four independent experiments. ${ }^{* *}, p<0.01$ vs. control group (Con); \#\#, $p<0.01$ vs. $A \beta_{25-35}$-treated alone group; $\dagger^{\dagger}, p<0.01$ vs. $A \beta+$ cilostazol group or $A \beta+$ rosiglitazone group. 


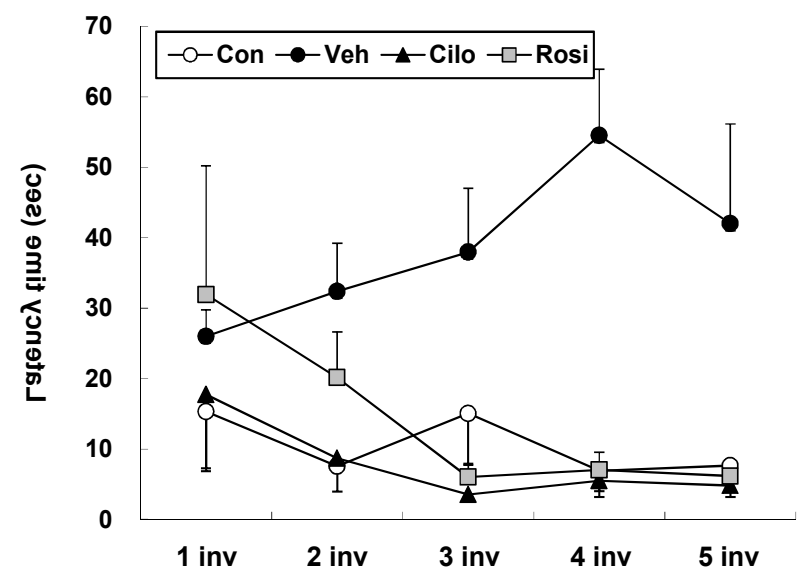

Fig. 5. Effect of cilostazol on spatial learning and memory in A $\beta_{25-35}$-injected mice by the Morris water maze test. The changes in escape latency time to reach the platform in mice treated with DMSO (Veh), cilostazol (Cilo; 20 $\mathrm{mg} / \mathrm{kg}$ ) or rosiglitazone (Rosi; $10 \mathrm{mg} / \mathrm{kg}$ ) at 4 weeks after $A \beta_{25-35}$ injection. $A \beta_{25-35}$ significantly increased escape latency time at 4 weeks after $A \beta_{25-35}$ injection ( $p<0.05$ vs control, Two-way ANOVA), which were reversed by cilostazol $(p<0.05$ vs vehicle, Two-way ANOVA). Results are shown as the mean \pm SEM and represent five independent experiments.

before $A \beta_{25-35}$ injection and once a day for 4 weeks post-surgery. Unilateral icv injection of $A \beta_{25-35}$ resulted in a significantly increased escape latency time in the target quadrant compared to control group at 4 weeks after $A \beta$ injection (Fig. 5, $p<0.05$ vs. control). Treatment with cilostazol $(20 \mathrm{mg} / \mathrm{kg})$ or rosiglitazone $(10 \mathrm{mg} / \mathrm{kg})$ significantly reduced the escape latency time in $A \beta_{25-35}$-injected mice ( $p<0.05$ vs. vehicle).

\section{Discussion}

Here, we report that a phosphodiesterase III inhibitor cilostazol strongly protected $A \beta_{25-35}$-induced cytotoxicity in mouse neuronal cells and significantly improved spatial learning and memory in $\mathrm{A} \beta_{25-35}$-injected mice as did rosiglitazone, a PPAR- $\gamma$ activator. Cilostazol also directly increased PPAR- $\gamma$ activity levels and restored the levels of proapoptotic Bax and antiapoptotic Bcl-2 that had been altered as a result of $A \beta_{25-35}$ treatment as did rosiglitazone, which were antagonized by GW9662, a PPAR- $\gamma$ antagonist. Therefore, the beneficial effects of cilostazol may contribute to the PPAR- $\gamma$ activity.

Increased $A \beta$ deposition is believed to have a central role in the pathogenesis of AD [8]. Many researchers have dem- onstrated that $A \beta$ triggered apoptotic degeneration $[9,14]$. To induce $\mathrm{AD}$-like in vitro and in vivo model, we used $\mathrm{A} \beta_{25-35}$ in this study. $A \beta_{25-35}$ is known as a toxic core fragment of full-length $A \beta_{1-40}[36,25]$ and a number of studies have demonstrated that $A \beta_{25-35}$ can mimic the neurotoxicity of $A \beta_{1-42}$ and dramatically decrease neuronal viability in multiple cellular systems $[1,37]$. Consistent with these reports, we observed $A \beta_{25-35}$ significantly reduced cell viability and increased the number of apoptotic-like cells in mouse neuronal cells and icv injection of $A \beta_{25-35}$ in C57BL/6J mice resulted in impaired cognitive function. Therefore, we believe that these in vitro and in vivo models are suitable for determining whether cilostazol affords protection against $A \beta$-induced cytotoxicity and cognitive dysfunction.

Activation of PPAR- $\gamma$ prevents A $\beta$-induced neurodegeneration [13]. Recently, PPAR- $\gamma$ activation has been reported to induce clearance of the $A \beta$ peptide [4] and repression of $\gamma$-secretase ( $\gamma$-site amyloid precursor protein cleaving enzyme) [10]; therefore, PPAR- $\gamma$ agonists have been expected to be effective for the prevention of $\mathrm{AD}$. Several studies using animal models of $\mathrm{AD}$ have shown that treatment with PPAR- $\gamma$ agonist attenuated learning and memory deficits $[5,20,24]$. In fact, it has been reported that treatment with rosiglitazone, a PPAR- $\gamma$ agonist, prevented cognitive impairment in patients with early $\mathrm{AD}$ in a preliminary study $[26,33]$. This beneficial effect of PPAR- $\gamma$ agonists in $\mathrm{AD}$ was mediated by controlling neuroinflammation and reducing neuronal death [19,34].

Cilostazol increases intracellular cAMP levels by inhibiting type III phosphodiesterase. 8-Bromo-cAMP and forskolin were reported to increase PPAR- $\gamma$ transcriptional activity [32] and protein kinase A pathway is an important modulator of PPAR- $\gamma$ transcriptional activity [17]. Recently, we reported that cilostazol significantly elevated endogenous PPAR- $\gamma$ transcriptional activity in COS-7 cells and human umbilical vein endothelial cells [22] and suppressed proinflammatory markers via activation of PPAR- $\gamma$ transcription in $\mathrm{db} / \mathrm{db}$ mice [23]. Therefore, cilostazol could decrease neuronal cell death and improve cognitive deficit via PPAR- $\gamma$ activation in $\mathrm{AD}$. As expect, in the present study, we observed that cilostazol increased PPAR- $\gamma$ transcriptional activity, as did rosiglitazone, which were antagonized by GW9662 in mouse neuronal cells. These results suggest that cilostazol exerts a pharmacological action similar to rosiglitazone for the activation of PPAR- $\gamma$ transcription. In addition, cilostazol treatment recovered cells from AB-induced cell 
death as did rosiglitazone and these effects were suppressed by GW9662. Furthermore, oral administration of cilostazol prevented the $A \beta_{25-35}$-induced spatial learning and memory deficits, as did rosiglitazone. These findings suggest that cilostazol could attenuate $A \beta_{25-35}$-induced neuronal cell injury, subsequently improving the cognitive decline in $\mathrm{AD}$, partly because of PPAR- $\gamma$ activation.

In the present study, we also found that cilostazol treatment attenuated the biochemical alterations associated with $\mathrm{A} \beta_{25-35}$-induced apoptotic cell death. The MTT assay indicated that $30 \mu \mathrm{M}$ cilostazol significantly protected neuronal cells from $A \beta$ toxicity. The neuroprotective effects were also confirmed by analysis of morphological nuclear changes (Fig. 3). The Bcl-2 family includes antiapoptotic members such as Bcl-2, and proapoptotic members such as Bax. Bax is potent regulators of cytochrome $\mathrm{c}$ release from mitochondria under a variety of stress conditions and $\mathrm{Bcl}-2$ prevents release of cytochrome $\mathrm{c}$ by heterodimerizing with Bax [35]. The ratio of Bax to $\mathrm{Bcl}-2$ has been reported to be correlated with apoptosis. Our results showed that cilostazol markedly decreased Bax/Bcl-2 ratio in a similar degree as did rosiglitazone, both of which were significantly inhibited by GW9662. The results suggest that cilostazol could prevent $A \beta_{25-35}$-induced apoptosis, at least in part, via PPAR- $\gamma$-mediated regulation of Bcl-2 and Bax expression.

In conclusion, a phosphodiesterase III inhibitor cilostazol rescues neuronal cells from $A \beta_{25-35}$-induced cell death and improves cognitive decline in AD mouse model through activation of PPAR- $\gamma$ transcription. Further study of the anti-apoptotic and anti-inflammatory properties of cilostazol may provide opportunities for novel pharmacological interventions aimed at preventing or palliating the consequences of $\mathrm{AD}$.

\section{Acknowledgement}

This work was supported for two years by Pusan National University Research Grant.

\section{References}

1. Agostinho, P., J. P. Lopes, Z. Velez, and C. R. Oliveira. 2008. Overactivation of calcineurin induced by amyloid-beta and prion proteins. Neurochem Int. 52, 1226-1233.

2. Arai, H. and T. Takahashi. 2009. A combination therapy of donepezil and cilostazol for patients with moderate Alzheimer disease: pilot follow-up study. Am J. Geriatr.
Psychiatry 17, 353-354.

3. Bermpohl, D., Z. You, E. H. Lo, H. H. Kim, and M. J. Whalen. 2007. TNF alpha and Fas mediate tissue damage and functional outcome after traumatic brain injury in mice. J. Cereb. Blood Flow Metab. 27, 1806-1818.

4. Camacho, I. E., L. Serneels, K. Spittaels, P. Merchiers, D. Dominguez, and B. De Strooper. 2004. Peroxisome-proliferator-activated receptor gamma induces a clearance mechanism for the amyloid-beta peptide. J. Neurosci. 24, 10908-10917.

5. Escribano, L., A. M. Simon, A. Perez-Mediavilla, P. Salazar-Colocho, J. Del Rio, and D. Frechilla. 2009. Rosiglitazone reverses memory decline and hippocampal glucocorticoid receptor down-regulation in an Alzheimer's disease mouse model. Biochem Biophys. Res. Commun. 379, 406-410.

6. Hardy, J. 1997. Amyloid, the presenilins and Alzheimer's disease. Trends Neurosci. 20, 154-159.

7. Hardy, J. 2006. A hundred years of Alzheimer's disease research. Neuron 52, 3-13.

8. Hardy, J. and D. J. Selkoe. 2002. The amyloid hypothesis of Alzheimer's disease: progress and problems on the road to therapeutics. Science 297, 353-356.

9. Harkany, T., T. Hortobagyi, M. Sasvari, C. Konya, B. Penke, P. G. Luiten, and C. Nyakas. 1999. Neuroprotective approaches in experimental models of beta-amyloid neurotoxicity: relevance to Alzheimer's disease. Prog. Neuropsychopharmacol. Biol. Psychiatry 23, 963-1008.

10. Heneka, M. T., M. Sastre, L. Dumitrescu-Ozimek, A. Hanke, I. Dewachter, C. Kuiperi, K. O'Banion, T. Klockgether, F. Van Leuven, and G. E. Landreth. 2005. Acute treatment with the PPARgamma agonist pioglitazone and ibuprofen reduces glial inflammation and Abeta1-42 levels in APPV717I transgenic mice. Brain 128, 1442-1453.

11. Hensley, K., J. M. Carney, M. P. Mattson, M. Aksenova, M. Harris, J. F. Wu, R. A. Floyd, and D. A. Butterfield. 1994. A model for beta-amyloid aggregation and neurotoxicity based on free radical generation by the peptide: relevance to Alzheimer disease. Proc. Natl. Acad Sci. USA 91, 3270-3274.

12. Hong, K. W., J. H. Lee, K. Y. Kima, S. Y. Park, and W. S. Lee. 2006. Cilostazol: therapeutic potential against focal cerebral ischemic damage. Curr. Pharm Des. 12, 565-573.

13. Inestrosa, N. C., J. A. Godoy, R. A. Quintanilla, C. S. Koenig, and M. Bronfman. 2005. Peroxisome proliferator-activated receptor gamma is expressed in hippocampal neurons and its activation prevents beta-amyloid neurodegeneration: role of Wnt signaling. Exp. Cell Res. 304, 91-104.

14. Jang, J. H. and Y. J. Surh. 2002. beta-Amyloid induces oxidative DNA damage and cell death through activation of c-Jun N terminal kinase. Ann. NY Acad Sci. 973, 228-236.

15. Jiang, C., A. T. Ting, and B. Seed. 1998. PPAR-gamma agonists inhibit production of monocyte inflammatory cytokines. Nature 391, 82-86.

16. Kaskie, B. and M. Storandt. 1995. Visuospatial deficit in dementia of the Alzheimer type. Arch Neurol. 52, 422-425. 
17. Lazennec, G., L. Canaple, D. Saugy, and W. Wahli. 2000. Activation of peroxisome proliferator-activated receptors (PPARs) by their ligands and protein kinase A activators. Mol. Endocrinol. 14, 1962-1975.

18. Lee, J. H., S. Y. Park, Y. W. Shin, K. W. Hong, C. D. Kim, S. M. Sung, K. Y. Kim, and W. S. Lee. 2006. Neuroprotection by cilostazol, a phosphodiesterase type 3 inhibitor, against apoptotic white matter changes in rat after chronic cerebral hypoperfusion. Brain Res. 1082, 182-191.

19. Luna-Medina, R., M. Cortes-Canteli, M. Alonso, A. Santos, A. Martinez, and A. Perez-Castillo. 2005. Regulation of inflammatory response in neural cells in vitro by thiadiazolidinones derivatives through peroxisome proliferator-activated receptor gamma activation. J. Biol. Chem 280, 21453-21462.

20. Mogi, M., J. M. Li, K. Tsukuda, J. Iwanami, L. J. Min, A. Sakata, T. Fujita, M. Iwai, and M. Horiuchi. 2008. Telmisartan prevented cognitive decline partly due to PPAR-gamma activation. Biochem Biophys. Res. Commun. 375, 446-449.

21. Nitta, A., A. Itoh, T. Hasegawa, and T. Nabeshima. 1994. beta-Amyloid protein-induced Alzheimer's disease animal model. Neurosci. Lett. 170, 63-66.

22. Park, S. Y., J. H. Lee, K. Y. Kim, E. K. Kim, S. J. Yun, C. D. Kim, W. S. Lee, and K. W. Hong. 2008. Cilostazol increases 3T3-L1 preadipocyte differentiation with improved glucose uptake associated with activation of peroxisome proliferator-activated receptor-gamma transcription. Atherosclerosis 201, 258-265.

23. Park, S. Y., H. K. Shin, J. H. Lee, C. D. Kim, W. S. Lee, B. Y. Rhim, and K. W. Hong. 2009. Cilostazol ameliorates metabolic abnormalities with suppression of proinflammatory markers in a $\mathrm{db} / \mathrm{db}$ mouse model of type 2 diabetes via activation of peroxisome proliferator-activated receptor gamma transcription. J. Pharmacol. Exp. Ther. 329, 571-579.

24. Pedersen, W. A., P. J. McMillan, J. J. Kulstad, J. B. Leverenz, S. Craft, and G. R. Haynatzki. 2006. Rosiglitazone attenuates learning and memory deficits in Tg2576 Alzheimer mice. Exp. Neurol. 199, 265-273.

25. Pike, C. J., A. J. Walencewicz-Wasserman, J. Kosmoski, D. H. Cribbs, C. G. Glabe, and C. W. Cotman. 1995. Structure-activity analyses of beta-amyloid peptides: contributions of the beta 25-35 region to aggregation and neurotoxicity. J. Neurochem 64, 253-265.

26. Risner, M. E., A. M. Saunders, J. F. Altman, G. C. Ormandy, S. Craft, I. M. Foley, M. E. Zvartau-Hind, D. A. Hosford, and A. D. Roses. 2006. Efficacy of rosiglitazone in a genetically defined population with mild-to-moderate Alzheimer's disease. Pharmacogenomics J. 6, 246-254.
27. Rosen, E. D., P. Sarraf, A. E. Troy, G. Bradwin, K. Moore, D. S. Milstone, B. M. Spiegelman, and R. M. Mortensen. 1999. PPAR gamma is required for the differentiation of adipose tissue in vivo and in vitro. Mol. Cell 4, 611-617.

28. Selkoe, D. J. 2000. Toward a comprehensive theory for Alzheimer's disease. Hypothesis: Alzheimer's disease is caused by the cerebral accumulation and cytotoxicity of amyloid beta-protein. Ann. $N Y$ Acad Sci. 924, 17-25.

29. Sung, S. M., D. S. Jung, C. H. Kwon, J. Y. Park, S. K. Kang, Y. K. Kim. 2007. Hypoxia/reoxygenation stimulates proliferation through PKC-dependent activation of ERK and Akt in mouse neural progenitor cells. Neurochem Res. 32, 1932-1939.

30. Takeda, S., N. Sato, K. Niisato, D. Takeuchi, H. Kurinami, M. Shinohara, H. Rakugi, M. Kano, and R. Morishita. 2009. Validation of Abeta1-40 administration into mouse cerebroventricles as an animal model for Alzheimer disease. Brain Res. 1280, 137-147.

31. Troy, C. M., S. A. Rabacchi, Z. Xu, A. C. Maroney, T. J. Connors, M. L. Shelanski, and L. A. Greene. 2001. beta-Amyloid-induced neuronal apoptosis requires c-Jun N-terminal kinase activation. J. Neurochem 77, 157-164.

32. Watanabe, M., K. Inukai, H. Katagiri, T. Awata, Y. Oka, and S. Katayama. 2003. Regulation of PPAR gamma transcriptional activity in 3T3-L1 adipocytes. Biochem Biophys. Res. Commun. 300, 429-436.

33. Watson, G. S., B. A. Cholerton, M. A. Reger, L. D. Baker, S. R. Plymate, S. Asthana, M. A. Fishel, J. J. Kulstad, P. S. Green, D. G. Cook, S. E. Kahn, M. L. Keeling, and S. Craft. 2005. Preserved cognition in patients with early Alzheimer disease and amnestic mild cognitive impairment during treatment with rosiglitazone: a preliminary study. Am J. Geriatr. Psychiatry 13, 950-958.

34. Yan, Q., J. Zhang, H. Liu, S. Babu-Khan, R. Vassar, A. L. Biere, M. Citron, and G. Landreth. 2003. Anti-inflammatory drug therapy alters beta-amyloid processing and deposition in an animal model of Alzheimer's disease. J. Neurosci. 23, 7504-7509.

35. Yang, J., X. Liu, K. Bhalla, C. N. Kim, A. M. Ibrado, J. Cai, T. I. Peng, D. P. Jones, and X. Wang. 1999. Prevention of apoptosis by $\mathrm{Bcl}-2$ : release of cytochrome $\mathrm{c}$ from mitochondria blocked. Science 275, 1129-1132.

36. Yankner, B. A., L. K. Duffy, and D. A. Kirschner. 1990. Neurotrophic and neurotoxic effects of amyloid beta protein: reversal by tachykinin neuropeptides. Science 250, 279-282.

37. Zhang, H. Y., Y. H. Liu, H. Q. Wang, J. H. Xu, and H. T. Hu. 2008. Puerarin protects PC12 cells against beta-amyloid-induced cell injury. Cell Biol. Int. 32, 1230-1237. 


\section{초록 : Amyloid $\beta$ 에 의해 유도된 신경세포 손상에 대한 phosphodiesterase III inhibitor인 cilostazol의 신경보호 효과 \\ 박선행 ${ }^{1}$ 김지현 ${ }^{1} \cdot$ 배순식 $^{2}$ 홍기환 ${ }^{2} \cdot$ 최병태 ${ }^{1} \cdot$ 신화경 ${ }^{1} \star$ \\ ( ${ }^{1}$ 부산대학교 한의학전문대학원 경락구조의학부, ${ }^{2}$ 부산대학교 의학전문대학원 약리학교실)}

Amyloid $\beta(\mathrm{A} \beta)$ 의 신경독성은 알츠하이머병의 주된 원인이 되고 이러한 신경독성은 일련의 신경세포 사멸반 응에 의해 일어난다고 알려져 있다. 본 연구에서는 알츠하이머병의 실험모델로 mouse primary neuronal cello에 $\mathrm{A} \beta_{25-35}$ 를 처리하여 세포독성을 유도하는 세포실험모델과 C57BL/6J mouse 뇌실에 $\mathrm{A} \beta_{25-35}$ 를 주입하여 인지장애 를 일으키는 동물실험모델을 이용하여 phosphodiesterase III 억제제인 cilostazol의 신경보호 효과에 대해 조사하 였다. $\mathrm{A} \beta_{25-35}$ 를 신경세포에 처리하면 세포생존율이 감소되었고, 세포사멸이 일어난 세포의 수도 증가되었다. 이 러한 $\mathrm{A}_{25-35}$ 에 의한 세포독성이 cilostazol처리에 의해 회복되었으며, peroxisome proliferator-activated receptor (PPAR)- $\gamma$ 항진제인 rosiglitazone 또한 동일한 회복효과를 나타내었다. Cilostazol과 rosiglitazone에 의한 이러한 회복효과가 PPAR- $\gamma$ 길항제인 GW9662에 의해 다시 억제되는 결과를 통해 cilostazol의 효과는 PPAR- $\gamma$ 가 매개 하는 신호전달이 관여함을 알 수 있었다. 직접 PPAR- $\gamma$ 활성화 정도를 측정한 결과, $\mathrm{AB}_{25-35}$ 처리에 의해 감소된 PPAR- $\gamma$ 활성화 정도가 cilostazol과 rosiglitazone에 의해 증가함을 관찰할 수 있었고, 이는 GW9662에 의해 다시 억제됨을 확인하였다. 게다가, cilostazol은 세포사멸이 일어난 세포의 수와 세포사멸 조절단백질인 Bax/Bcl-2의 비율도 감소시켰다. Cilostazol $\left(20 \mathrm{mg} / \mathrm{kg}\right.$, 구강투여)을 C57BL/6J mice 뇌실에 $\mathrm{A} \beta_{25-35}$ 를 주입하기 2주 동안 전처 리하고, $\mathrm{A} \beta_{25-35}$ 주입 후 4 주 동안 처리하면, 기억력과 학습능력을 증진시킨다는 결과를 water maze 실험을 통해 알 수 있었으며, rosiglitazone $(10 \mathrm{mg} / \mathrm{kg})$ 을 먹인 동물에서도 동일한 결과를 얻을 수 있었다. 본 연구를 통해서 cilostazol이 PPAR- $\gamma$ 활성화를 통해 $\mathrm{A} \beta_{25-35}$ 로 인한 신경세포 손상과 세포사멸을 약화시켜, 신경세포의 생존을 증진시키고, 알츠하이머에서 인지장애를 개선할 것으로 생각된다. 따라서, phosphodiesterase III 억제제인 cilostazol은 알츠하이머 질병 치료에 새로운 전략이 될 수 있을 것이다. 